\title{
Firm Performance: Definition and Measurement Models
}

Omar Taouab

\author{
Zineb Issor
}

Laboratory of Management Sciences, ENCG Kenitra, Ibn Tofail University, Morocco

\begin{abstract}
The business environment of this new century has undertaken several changes, creating more and more complexity and uncertainty. In this changing environment, which characterizes the global economy today, firms face severe competitive pressure to do things better, faster, and low-priced. They need to cope with a growing number of challenges arising from their environment, and also increase their ability to adapt. Nowadays, continuous performance is the objective of any firm. This is because it is only through performance that companies are able to experience development and make progress. Consequently, assessing and measuring business performance is of significant importance, since companies are constantly seeking effective and efficient results.
\end{abstract}

Keywords: Firm performance, Performance management, Performance measurement, Competitiveness.

\section{Introduction}

Most companies are seeking to improve their performance in any way possible. The winning card can be held by those who endeavour to innovate, to obtain and sustain performance. Thus, competing in a continuously changing environment is very necessary to comprehend and monitor performance.

Therefore, assessing the performance of organizations has always been of interest to management teams and researchers. In addition, measuring business performance in today's economic environment is a critical issue for academic scholars and practising managers. Researchers have extended efforts to determine measures for the concept of performance. In this regard, there is an incomplete literature and an on-going debate on the issue of firms' performance. 
This paper focuses on giving an overview of firm performance definitions and the most common performance measurement models.

\section{Firm Performance}

Successful firms represent a key ingredient for developing nations. Many economists consider them similar to an engine in determining their economic, social, and political development. To survive in a competitive business environment, every firm should operate in conditions of performance.

Nowadays, firm performance has become a relevant concept in strategic management research and is frequently used as a dependent variable. Although it is a very common notion in the academic literature, there is hardly a consensus about its definition and measurement.

However, due to the absence of any operational definition of firm performance upon which the majority of scholars consent, there would naturally be diverse interpretations suggested by various people according to their personal perceptions. Definitions of this concept may be abstract, or general, less or clearly defined.

\section{Firm Performance: From the 50s to the End of the Last Decade of the Twentieth Century}

In the 50s, firm performance was considered as the equivalent of organizational efficiency, which represents the degree to which an organization, as a social system with some limited resources and means, achieves its goals without an excessive effort from its members. The criteria used for assessing performance are productivity, flexibility, and interorganizational tensions (Georgopoulos \& Tannenbaum, 1957).

Later in the 60s and 70s, organizations began to explore new ways to evaluate their performance. During this time, performance was defined as an organization's ability to exploit its environment for accessing and using the limited resources (Yuchtman \& Seashore, 1967).

Price (1968) considers that performance is synonymous with organizational effectiveness, and identifies as appreciation criteria: productivity, conformity, and institutionalization.

Moh (1972) identifies the following as the criteria for evaluating performance: productivity, flexibility, and adaptability.

Harrison (1974) defines performance as the outcome of evaluating effort.

Lupton (1977) treated the notion of organizational performance in the most careful and clear manner in comparison with other researchers in the same period. According to Lupton, in an effective organization, the productivity rate and levels of motivation and satisfaction of its members are 
high, while rates of turnover, costs, labour unrest are low or absent. However, according to Katz and Kahn (1978), the effectiveness and efficiency of an organization were similar, and both were crucial components of the global organizational performance, which can be assessed through maximizing the entire returns of all kinds.

In the 1980s, the firm performance depended on its ability to create value for its clients (Porter, 1986).

Robbins (1987) defined performance as the extent to which an organization, as a social system, could consider both its means and ends.

Cherrington (1989) considered performance as a concept of success or effectiveness of an organization, and as an indication of the organizational manner that it is performing effectively to achieve its goals successfully.

During the following decade, Adam (1994) considered organizational performance as deeply dependent on the employees' performance quality. He believed that in order to guarantee a high quality organizational performance, it is essential to have regular exposure of the workers of the company to new and up-to-date knowledge and skills, which would, in turn, help them keep up with the new changes happening in the market, and, ultimately, increase the quality of organizational performance.

Cohen (1994) puts the notice of identity between performance and efficiency, following the results obtained by the entity in relation to resources used.

Bourguignon (1997) assimilates performance with an "action", with a certain "behaviour" (in terms of a dynamic view, meaning, "to perform") and not just as a "result" (in terms of a static view).

Harrison and Freeman (1999) confirmed that an effective organization with high standard of performance level is the one that keeps the demands of its stakeholders satisfied.

\section{Firm Performance: From the First Decade of the Twenty-First Century}

In the first decade of the twenty-first century, the definition of organizational performance principally focused on the capability and ability of an organization to efficiently exploit the available resources to achieve accomplishments consistent with the set objectives of the company, as well as considering their relevance to its users (Peterson, Gijsbers, \&Wilks, 2003).

Verboncu and Zalman (2005) appreciated that performance is a particular result obtained in management, economics, and marketing that gives characteristics of competitiveness, efficiency, and effectiveness to the organization and its structural and procedural components. 


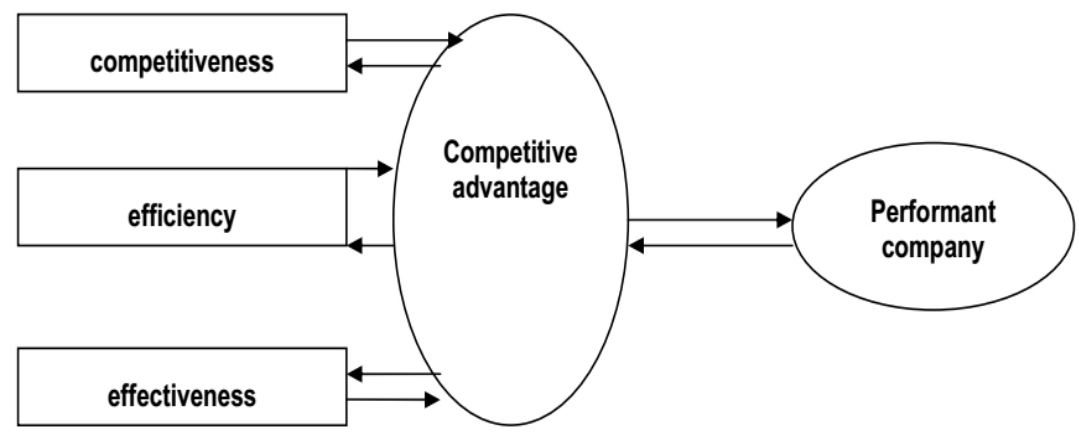

Figure 1. Factors that drive performance (Verboncu \& Zalman, 2005)

Lebans and Euske (2006) provided a set of definitions to illustrate the concept of organizational performance:

- Performance is a set of financial and nonfinancial indicators that offer information on the level of accomplishment of objectives and results.

- Performance is dynamic, requiring judgment and interpretation.

- Performance may be illustrated by using a causal model that describes how future results can be affected by current actions.

- Performance may be understood differently depending on the person involved in the assessment of the firm performance.

- To define the concept of performance, it is necessary to know its fundamentals characteristics to each area of responsibility.

- To report a firm's performance level, it is necessary to be able to quantify the results.

Siminica (2008) appreciates that a firm is performant when it is at the same time efficient and effective. Therefore, the performance is a function of two variables, efficiency and efficacy.

Colase (2009) considers the word performance as a bag-word because it covers various and different notions such as growth, profitability, return, productivity, efficiency, and competitiveness.

Bartoli and Blatrix (2015) believed that the definition of performance should be achieved through items such as piloting, evaluation, efficiency, effectiveness, and quality.

\section{Firm Performance Measurement System}

Finding a measurement for the performance of the firm enables the comparison of performances over different periods.

Since the 1980s, when literature on Performance Measurement (PM) first emerged, research on PM developed more. In the traditional context, 
small companies operations were simple and the most important PM focused on cash flow.

Some scholars, like Pursell (1980), shifted their attention on the PM of the whole business unit (typically plant level and division level) and endeavoured to investigate the standards, criteria, and measures of performance.

However, several remarkable changes have occurred in the corporate world in the past few decades in terms of the introduction of national and international awards, improvement initiatives, organizational roles, work maturity, external demands, increased competition, and advanced technology. These changes have resulted in companies encountering impressive competition resulting from the improvements occurring in product quality, development of flexibility and reliability, the expansion of product variety, and its importance on innovation (Fry, Karwan, \& Baker, 1993).

These approaches towards PM have led to different definitions of it, and there is little agreement regarding its main components and characteristics (Dumond, 1994).

Lebas (1995) considers that through the measurement, people can create simplified numerical concepts from complex reality for its easy communication and action. The simplification of this complex reality is conducted through the measurement of the requirements of successful management.

According to Atkinson et al. (1997), a performance measurement system must essentially do four things:

1. Help the company to assess whether it is receiving the expected contribution of employees and suppliers;

2. Help the company to assess whether each stakeholder group is supporting the company to achieve its main objectives;

3. Assist the company in building and implementing processes that contribute in achieving the strategic objectives;

4. Help the company to assess and monitor strategic planning in accordance with the agreements negotiated with key stakeholders.

For Ghalayini and Noble (1996), the globalization introduced a nontraditional approach changing the strategic focus of low production costs into quality, flexibility, and delivery focus. This showed that traditional concepts were very limited and open to new models. 


\begin{tabular}{|l|l|}
\hline Traditional Performance Measures & Non-traditional Performance Measures \\
\hline Based on out-dated traditional accounting system & Based on company strategy \\
Mainly financial measures & Mainly non-financial measures \\
Intended for top and senior managers & Intended for all employees \\
Late metrics (weekly or monthly) & On-time metrics (hourly or daily) \\
Difficult, confusing, and misleading & Simple, accurate and easy to use \\
Lead to employee frustration & Lead to employee satisfaction \\
Neglected at the shop floor & Frequently used at the shop floor \\
Have a fixed format & Have no fixed format (depends on needs) \\
Do not vary between locations & Vary between locations \\
Do not change over time & Change over time as the need changes \\
Intended mainly for monitoring performance & Intended to improve performance \\
Not applicable for JIT, TQM, RPR, OPT, etc. & Applicable \\
Hinders continuous improvement & Support continuous improvement \\
\hline
\end{tabular}

Table 1. A comparison between traditional and non-traditional performance measures

(Ghalayini \& Noble, 1996)

Measurement of performance can offer significant invaluable information to allow management monitoring of performance, report progress, improve motivation and communication, and pinpoint problems (Waggoner, Neely \& Kennerley, 1999).

Finding ideal concept for managing and measuring business performance is a complex problem. Additionally, experts represented by consulting firms, business managers or academics have been leading various discussions about it. More so, there is a conflict between the use of traditional indicators for measuring performance and modern indicators.

Ittner and Larcker (2003) point out the mistakes that firms make when trying to measure the non-financial performance:

1. Lack of Alignment between Measurements with Strategy: A key challenge for firms is to find out which non-financial measures they need to implement.

2. Validate the Measurements: Companies do not validate the model, which leads to the measuring of many things, and most of them are irrelevant.

3. Inability to set up the right goals and measures.

4. Wrong Measurements: Many companies use metrics that have no statistical validity.

Tangen (2004) indicates that many companies still rely on the traditional quantitative financial performance measurement systems.

Man (2006) determined that measures of performance are divided into four categories: Financial, non-financial, tangible, and intangible.

According to Gimbert et al. (2010), performance measurement system is a concise and defined set of measures (financial or non-financial) that supports the decision-making process of an organization by collecting, processing, and analyzing quantified data of performance information. 
From the above, it is evident that the most important function of performance measurement is to evaluate whether or not the organisational strategy is attained.

\section{Common Models of Firm Performance Measurement}

\section{The Balanced Scorecard}

The Balanced Scorecard (BSC) model was developed in the early 1990's by Robert Kaplan and David Norton. It is a tool used for describing, elaborating, and implementing a vision and the strategy of a firm into fixed targets and clear set of financial and nonfinancial performance indicators.

The introduction of BSC means that the goals, the indicators, and the strategic actions are assigned to concrete perspectives (Horvath et al., 2004). The Balanced Scorecard translates the mission and the organization strategy into a set of performance indicators that offers a model for the performance measurement system.

The model below shows the organizational performance through four perspectives: financial, customer, innovation and learning, and internal processes.

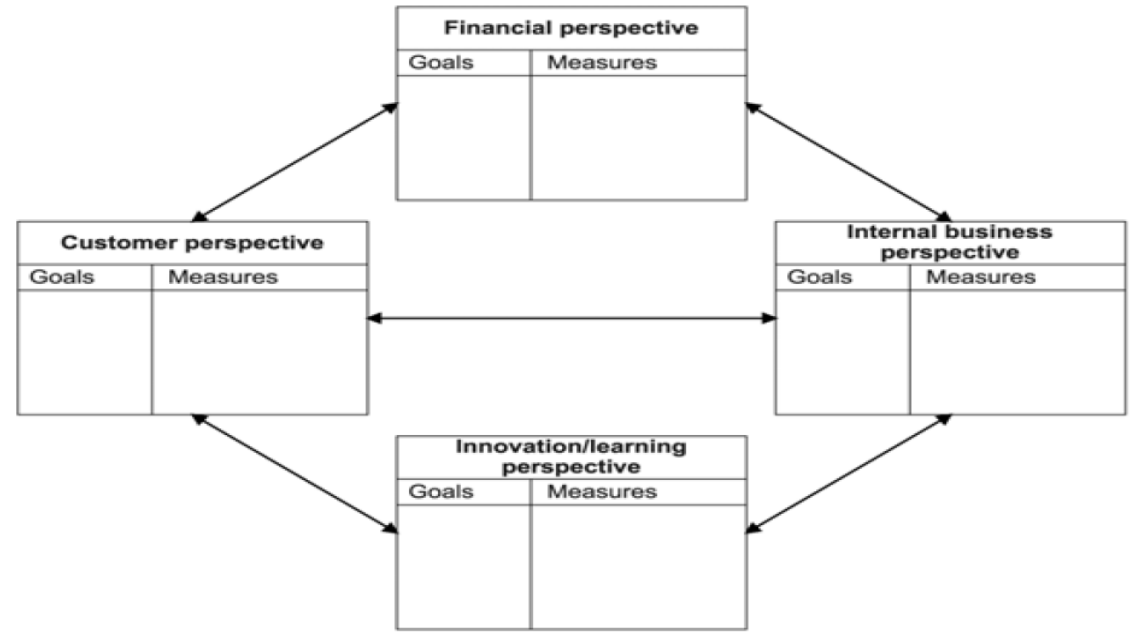

Figure 2. Balanced Scorecard (BSC) (Kaplan et al., 1992)

- Financial Perspective (How do we look at shareholders?): Controlling financial resources is very important for the success of the firm. Most of the organizations focus on financial results and ignore the other perspectives.

- Customer Perspective (How do customers see us?) : Knowing what customers want in terms of quality, costs and distribution, and the most important thing, what they want in the future from the organization.

- Internal Processes Perspective (What must we excel at?) : Understanding how internal processes work is very essential for the organization to achieve 
its goals and to know how to add the expected value to the products or services that the customers purchase.

- Innovation and Learning Perspective (Can we continue to improve and create value?): All the achievements from the customer, internal processes, and financial perspective are strictly linked to the organizational capabilities to train and develop its human resources and innovation system.

\section{The Performance Prism}

The Performance Prism (PP) was developed by a team of experienced consultants and researchers in performance measurement area (Neely, Adams, \& Kennerley, 2002). They described a comprehensive measurement system that addresses the main business issues to which a wide variety of organisations (profit and non-profit) will be capable to relate (Neely, Adams \& Crowe, 2001).

The performance prism is considered as a second-generation PM system (Michaela et al., 2012). It is a tool used by the management teams to influence their thinking when the strategic questions that need to be asked are established. In addition, it consists of five interrelated perspectives:

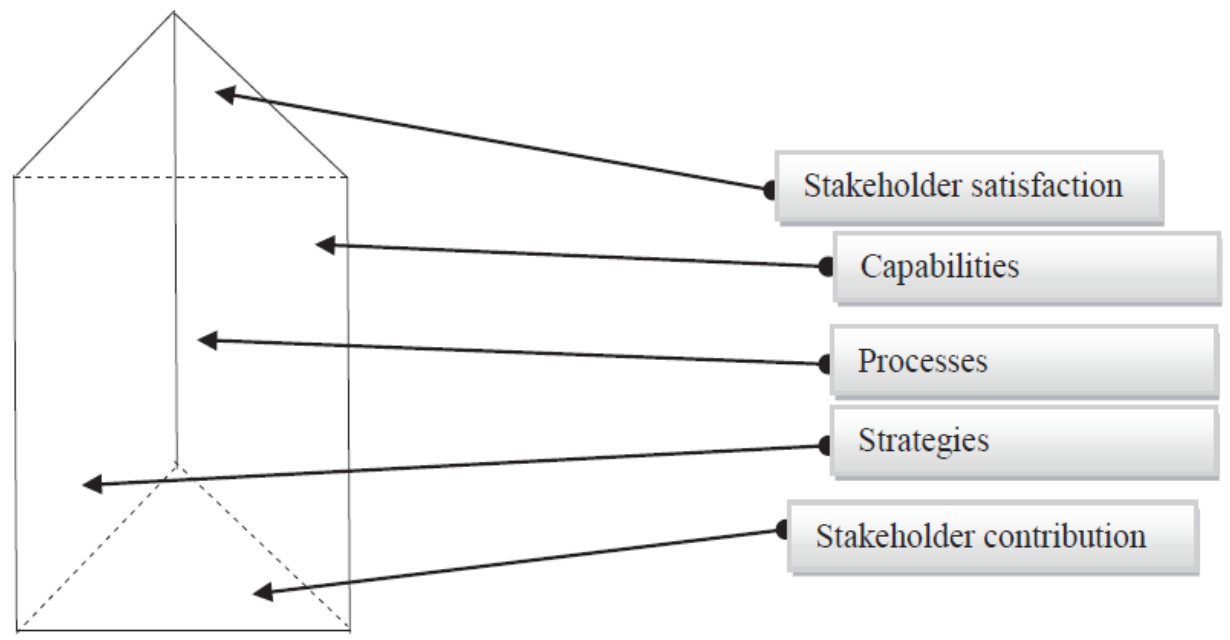

Figure 3. The performance prism (Neely et al., 2002)

- Stakeholder Satisfaction: Who are the stakeholders and what do they want and need?

- Capabilities: What are the competences needed by the organization to be able to make the processes work? (The combination of people, practices, technology, and infrastructure that allow the execution of the firm's business processes, now and in the future) 
- Processes: What are the processes we have to put in place in order to allow our strategies to work effectively?

- Strategies: What are the strategies we require to ensure the wants and needs of our stakeholders?

- Stakeholder Contribution: What do we want and need from stakeholders to preserve and develop our capabilities?

\section{The Malcolm Baldrige Model}

Malcolm Baldrige National Quality Award (MBNQA) was instituted in 1987 by the U.S. Commerce Department, and has the role to encourage the American businesses and all the other organizations, to practice an efficient control of quality for products and services, to evaluate quality improvement efforts, and to reward and publicize the efforts of successful organizations.

For over 20 years, the model has been used by thousands of U.S. organizations. It was created to offer an excellence quality standard and to help companies to reach a high level of performance (Garvin, 1991).

Malcolm Baldrige National Quality Award (MBNQA) is a set of interrelated fundamental values and concepts found in high performing organizations, which are illustrated by seven linked categories:

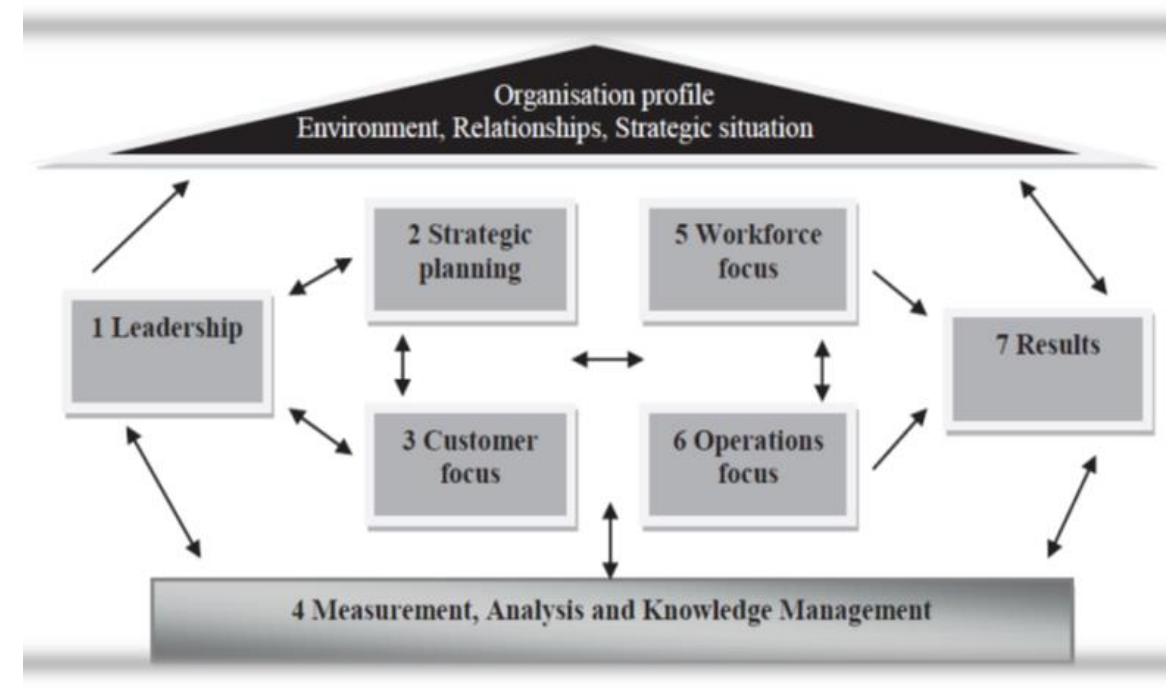

Figure 4. Malcolm Baldrige model - Criteria for performance excellence

1) Leadership: Examines how senior executives lead and maintain the organization and how the organization addresses governance, ethical, legal, and community responsibilities.

2) Strategic Planning: Examines how the organization sets strategic guidance and how it identifies and deploys key action plans. 
3) Customer Focus: Examines how the organization identifies expectations and requirements of customers and markets, and builds relationships with customers to satisfy and retain them.

4) Measurement, Analysis, and Knowledge Management: Examines the management, use, analysis, and development of data and information to support key organization processes as well as how the organization evaluates its performance.

5) Workforce Focus: Examines how the organization engages, organizes, and develops all those who are actively involved in accomplishing the work of the organization to improve full potential, and how the workforce is aligned with the organization's goals.

6) Operations Focus: Examines aspects of how key production/delivery and support processes are designed, managed, and developed.

7) Results: Examines the improvement of the organization's performance in its key business areas such as: customer satisfaction, financial and marketplace, workforce, product/service, operational effectiveness, and leadership.

The model allows any organization to attain its objectives, to improve its results and become more competitive, and work in alignment with its plans, processes, decisions, peoples, actions, and results.

\section{The Performance Pyramid}

Another important model is the Performance Pyramid. It was proposed by Cross and Lynch (1992).The main aim of the performance pyramid is to link the strategy of the organisation with its operations by translating objectives from the top down (based on customer priorities) and measures from the bottom up (Tangen, 2004).

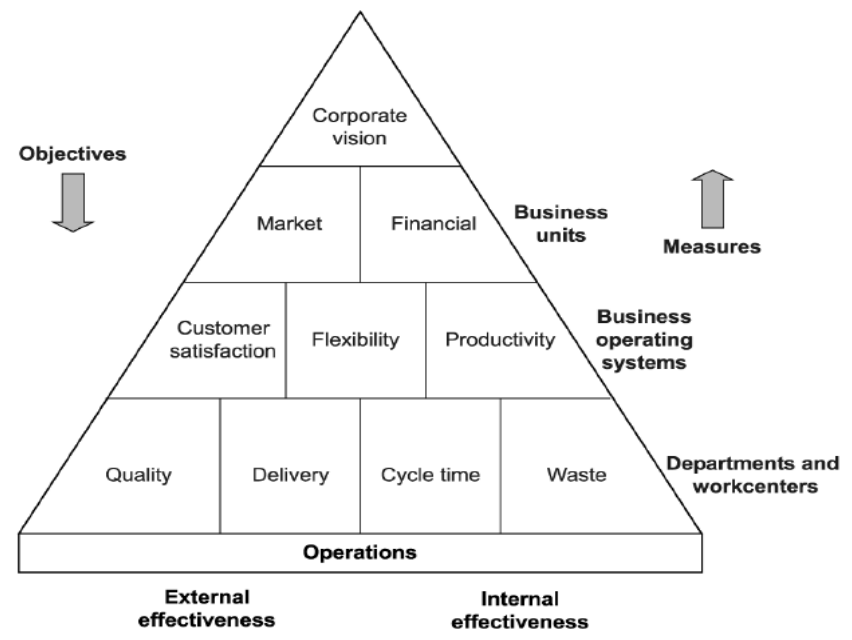

Figure 5. Performance Pyramid (Tangen, 2004) 
The Performance Pyramid contains four levels of objectives that affect the external effectiveness of the organization (left side of the pyramid) and simultaneously its internal effectiveness (right side of the pyramid).

1. At the first level, the development of a company's performance pyramid starts with defining an overall corporate vision, which is then translated into individual business unit objectives.

2. At the second level of the pyramid, short-term goals of cash flow and profitability are set as well as long-term targets of growth and market position.

3. The third level contains day-to-day operational measures (customer satisfaction, flexibility and productivity).

4. The last level includes four key performance measures (quality, delivery, cycle time and waste).

\section{Conclusion}

A well performing firm can bring high and long-term profits, which will generate employment opportunities and improve the income of individuals. Furthermore, financial profitability of a firm will enhance the returns of its employees, have better production units, and bring products of higher quality for its customers. This process cannot be possible without an outcome measurement.

Therefore, performance measurement is very important for the firm's effective management. It serves as a main provider to the perceptual and organization/control abilities of the firm. Performance requires measurement to study and identify the management strategy; to predict future internal and external situations; to monitor state and behaviour relative to its aims; and to make decisions in the needed periods.

\section{References:}

1. Adam, E.E. (1994). Alternative quality improvement practices and organization performance. Journal of Operations Management (pp. 2744).

2. Al-Matari, E.M., Al-Swidi, A.K., \& Bt Fadzil, F.H. (2014). The Measurements of Firm Performance's Dimensions. In the Asian Journal of Finance \& Accounting (pp. 24-49).

3. Atkinson, A., Waterhouse, J., \& Wells, R. (1997). A Stakeholder Approach to Strategic Performance Measurement. Sloan Management Review, 38, 3, 5, Spring.

4. Bartoli, A. \& Blatrix, C. (2015). Management dans les organizations publiques - 4ème édition. Dunod, Paris.

5. Ben Said, H. (2014). Determinants of Firm Performance: A Comparison of European Countries. In the International Journal of Economics and Finance (pp. 243-249). 
6. Bourguignon, A. (1997). Sous les pavés la plage...ou les multiples fonctions du vocabulaire comptable: l'exemple de la performance. Comptabilité, Contrôle, Audit. Tome 3 -Volume I (pp.89 à 101).

7. Cherrington, D.J. (1989). Organizational behavior: The management of individual and organizational performance. Allyn \& Bacon.

8. Cohen, E. (1994). Analyse financière. Economica, Paris.

9. Friebel, G. \& Schweiger, H. (2012). Management quality, firm performance and market pressure in Russia. In the European Bank for Reconstruction and Development. Working Paper No 144.

10. Fry, T., Karwan, K., \& Baker, W. (1993). Performance measurement systems and time-based manufacturing. Production planning \& control (pp. 102-111).

11. Gavrea, C., Ilieş, L., \& Egerean, R. (2011). Determinants of organizational performance: The case of Romania. In Management \& Marketing Challenges for the Knowledge Society (pp. 285-300).

12. Garvin, D. A. (1991). How the Baldrige Award Really Works. Harvard Business Review Nov-Dec, 69(6), (pp. 80-95).

13. Georgopoulos, B.S. \& Tannenbaum, A.S. (1957). A study of organizational effectiveness. American Sociological Review (pp. 534540).

14. Ghalayini, A.M. \& Noble, J.S. (1996). The changing basis of performance measurement. International Journal of Operations \& Production Management 16(8): (pp. 63-80).

15. Gimbert, X., Bisbe, J., \& Mendoza, X. (2010). The role of performance measurement systems in strategy formulation processes. Long Range Planning 43(4): (pp. 477-497).

16. Hansen, G.S. \& Wernerfelt, B. (1989). Determinants of Firm Performance: The Relative Importance of Economic and Organizational Factors. In the Strategic Management Journal (pp. 399411).

17. Harrison, J.S. \& Freeman, R.E. (1999). Stakeholders, social responsibility, and performance: Empirical evidence and theoretical perspectives. The Academy of Management Journal (pp. 479-485).

18. Horváth et al. (2004). Nová koncepce controllingu: cesta k účinnému controllingu. Praha:Profess Consulting.

19. Ittner, C. D., \& Larcker, D. F. (2003). Coming up short on nonfinancial performance measurement. Harvard Business Review, 81, 11, (pp. 8895).

20. Ivanov, C. \& Avasilcăi, S. (2014). Performance measurement models: an analysis for measuring innovation processes performance. In Procedia - Social and Behavioral Sciences (pp. 397-404). 
21. Kaplan, R.S. \& Norton, P.D. (1992). The balanced scorecard: Measures that drive performance. Harvard Business Review. 70(1): (pp.71-79).

22. Katz, D. \& Kahn, R.L. (1978). The social psychology of organizations;

23. Kellen, V. (2003). Business Performance Measurement: At the Crossroads of Strategy, Decision-Making, Learning and Information Visualization. Information Visualization 1 (312) (pp. 1-36).

24. Lebans, M. \& Euske, K. (2006). A conceptual and operational delineation of performance. Business Performance Measurement. Cambridge University Press.

25. Lebas, M. (1995). Performance measurement and performance management. International Journal of Production Economics, Volume 41, Issues 1-3, (pp. 23-35).

26. Loecker, J.D. \& Goldberg, P.K. (2013). Firm performance in a global market. In the National Bureau of Economic Research Working Paper Series. Working Paper 19308.

27. Lupton, T. (1977). Organizational Behavior and Performance. London: The Macmillan Press.

28. Lynch, R.L. \& Cross, K.F. (1992). MeasureUp! Yardsticks for Continuous Improvement. Basilblackwell, Oxford, U.K.

29. Man, Y.S. (2006). Performance Measurement and Management of Third Party Logistics: An Organizational Theory Approach. Hong Kong Baptist University.

30. Michaela, S. \& Marketa, S. (2012). Review and Comparison of Performance Measurement Systems. Journal of Organizational Management Studies. Article ID 114900, 13 pages.

31. Mirza, S. \& Javed, A. (2013). Determinants of financial performance of a firm: Case of Pakistani stock market. In the Journal of Economics and International Finance (pp. 43-52).

32. Neely, A., Adams, C., \& Crowe, P. (2001). The Performance Prism in Practice. Measuring Business Excellence, Vol. 5 Issue: 2, (pp.6-13).

33. Neely, A., Adams, C., \& Kennerley, M. (2002). The Performance Prism: The Scorecard for Measuring and Managing Business Success. Financial Times, Prentice Hall, London.

34. Pintea, M. \& Achim, M. (2010). Performance - an evolving concept. Annals of University of Craiova - Economic Sciences Series, vol. 2, issue 38, 12. JEL-codes: G00 G30.

35. Pursell, R.B. (1980). Administering divisional incentive compensation. Compensation \& Benefits Review (p. 15).

36. Robbins, S.P. (1987). Organizational Theory: Structure, Design, and Application. San Diego: Prentice-Hall. 
37. Roshan, D. \& Jenson, J. (2014). Study on performance measurement systems: Measures and Metrics. In the International Journal of Scientific and Research Publications.

38. Santos, J.B. \& Brito, L.A.L. (2012). Toward a Subjective Measurement Model for Firm Performance. In the Brazilian Administration Review (pp. 95-117).

39. Striteska, M. \& Spickova, M. (2012). Review and Comparison of Performance Measurement Systems. In the Journal of Organizational Management Studies (13 pages). IBIMA Publishing.

40. Tangen, S. (2004). Performance measurement: from philosophy to practice. International Journal of Productivity and Performance Management, Vol. 53, No. 8, (pp. 726-737), Issn 1741-0401.

41. Verboncu, I. \& Zalman, M. (2005). Management şi performanţe, Editura Universitară.

42. Waggoner, D., Neely, A., \& Kennerley, M. (1999). The forces that shape organizational performance measurement systems. An interdisciplinary review. International Journal of Production Economics, Volumes 60-61, (pp. 53-60).

43. Yuchtman, E. \& Seashore, S. (1967). Factorial Analysis of Organizational Performance. Administrative Science Quarterly (pp. 377-395).

44. Zulkiffli, S. \& Perera, N. (2011). A literature analysis on business performance for SMES - subjective or objective measures? Conference on Interdisciplinary Business and Economics Research (pp. 1-9). Bangkok, Thailand: Society of Interdisciplinary Business Research (SIBR). 